LWSA

PAPER - OPEN ACCESS

\title{
Analisis Perilaku Hearding Investor Pada Saham LQ-45 di Pasar Modal Indonesia
}

\author{
Author $\quad$ : Hafni Zubaedah Pasaribu \\ DOI $\quad: 10.32734 /$ lwsa.v1i2.215 \\ Electronic ISSN : :2654-7066 \\ Print ISSN : 2654-7058
}

Volume 1 Issue 2 - 2018 TALENTA Conference Series: Local Wisdom, Social and Arts

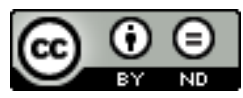

This work is licensed under a Creative Commons Attribution-NoDerivatives 4.0 International License.

Published under licence by TALENTA Publisher, Universitas Sumatera Utara
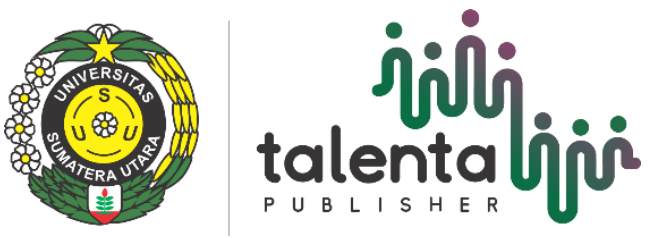


\title{
Analisis Perilaku Hearding Investor Pada Saham LQ-45 di Pasar Modal Indonesia
}

\author{
Hafni Zubaedah Pasaribu ${ }^{a}$, Isfenti Sadalia ${ }^{a}$ \\ ${ }^{a}$ Fakultas Ekonomi dan Bisnis, Universitas Sumatera Utara, Medan, Indonesia, 20155 \\ hafnizubaedah@gmail.com
}

\begin{abstract}
Penelitian ini menguji keberadaan perilaku herding investor pada saham LQ-45 di Pasar Modal Indonesia. Menggunakan model Cross-Sectional Absolute Deviation (CSAD) yang diusulkan oleh Chang, Cheng dan Kharona (2000). Variabel dependen dalam penelitian ini adalah Cross-Sectional Absolute Deviation (CSAD). Variabel independen dalam penelitian ini adalah return pasar. Jenis penelitian ini adalah penelitian asosiatif. Populasi yang digunakan adalah perusahaan yang terdaftar di Indeks LQ-45. Adapun yang menjadi sampel adalah 29 perusahaan. Data yang digunakan adalah data harian harga penutupan saham perusahaan dan harga penutupan indeks saham LQ-45 selama periode Januari 2013 sampai Desember 2015. Pengujian hipotesis menggunakan teknik analisis regresi sederhana dengan taraf signifikansi 5\%. Hasil penelitian menunjukkan bahwa pada saat kondisi pasar turun dan kondisi pasar naik, tidak ditemukan adanya perilaku herding di Pasar Modal Indonesia.
\end{abstract}

Keywords: Perilaku herding; CSAD; Indeks pasar LQ-45.

\section{Pendahuluan}

Seiring dengan pesatnya perkembangan investasi di pasar modal, perilaku keuangan sangat berperan dalam pengambilan keputusan investor. Pengambilan keputusan investasi bagi investor akan sangat dipengaruhi oleh informasi yang didapat dan pengetahuan investor tentang investasi tersebut. Dalam pasar modal terdapat dua jenis investor berdasarkan orientasi investasinya, yaitu investor orientasi jangka panjang dan investor orientasi jangka pendek. Pada umumnya investor yang berorientasi jangka panjang tidak begitu terpengaruh dengan adanya isu pasar, karena telah melakukan analisis fundamental perusahaan yang dipilih untuk melakukan investasi. berbeda dengan investor yang berorientasi pada jangka pendek. Investor yang berorientasi jangka pendek cenderung mengikuti trend pasar, saat harga saham menurun investor memutuskan untuk membeli, dan pada saat harga saham tinggi investor memutuskan untuk menjual saham tersebut. Seringkali investor bertindak secara tidak rasional saat kondisi pasar modal suatu negara akan goyah, hal ini terlihat dari indeks pasar yang menurun diikuti dengan harga saham yang menurun. Melihat seorang investor menjual saham dikarenakan kepanikan, maka investor lain akan langsung mengikuti langkah investor tersebut untuk menjual sahamnya, tindakan penjualan ini disebut sebagai perilaku herding.

Menurut Cristy dan Huang (1995) dalam Gunawan (2011), perilaku herding adalah kecenderungan perilaku investor untuk mengikuti konsensus pasar dan mengikuti perilaku investor lain tanpa melakukan analisis fundamental ekonominya, sehingga saat terjadi penurunan harga saham investor akan mengambil tindakan untuk menjual saham. Perilaku herding dianggap rasional saat investor menangkap sinyal yang sama dan membuat keputusan yang sama karena tindakan untuk memaksimalkan keuntungan. Perilaku herding yang bersifat tidak rasional terjadi pada saat 
investor mengambil sebuah keputusan karena panik dan emosi melihat investor lain menjual saham sehingga investor tersebut ikut melakukan penjualan saham. Perilaku herding banyak terjadi di negara berkembang karena sektor finansial dari negara tersebut tidak terlalu berkembang dan teratur, tidak banyak informasi yang tersedia mengenai pasar modal dan perusahaan yang terdaftar di dalam pasar modal tersebut, serta aliran uang masuk dan keluar tidak stabil. Kinerja perekonomian Indonesia menjadikan Indonesia sebagai salah satu emerging market yang menarik untuk berinvestasi, hal ini dikuatkan oleh penelitian yang dilakukan oleh Chang et al (2000) dalam Chasanah (2015), yang menyatakan bahwa terdapat aktivitas herding pada emerging market saat itu yaitu di negara Taiwan dan Korea Selatan.

Menurut Kole dan Dijk (2010) dalam Ramadhan (2016), dalam pasar keuangan bahwa banyak investor memiliki ekspektasi yang sama, pada saat yang bersamaan, terhadap harga dan imbal hasil di masa yang akan datang. Adanya istilah bullish dan bearish pada pasar saham merupakan gambaran dari persepsi tersebut. Bullish adalah kondisi pasar naik yang ditandai dengan imbal balik pasar bernilai positif (tinggi). Sedangkan bearish adalah kondisi pasar turun yang ditandai dengan imbal balik pasar bernilai negatif (rendah). dalam Indeks Harga Saham Gabungan pada tahun 2013-2015 sudah mencakup kondisi pasar sedang bullish dan bearish.

Sumber: IDX Fact Book 2016

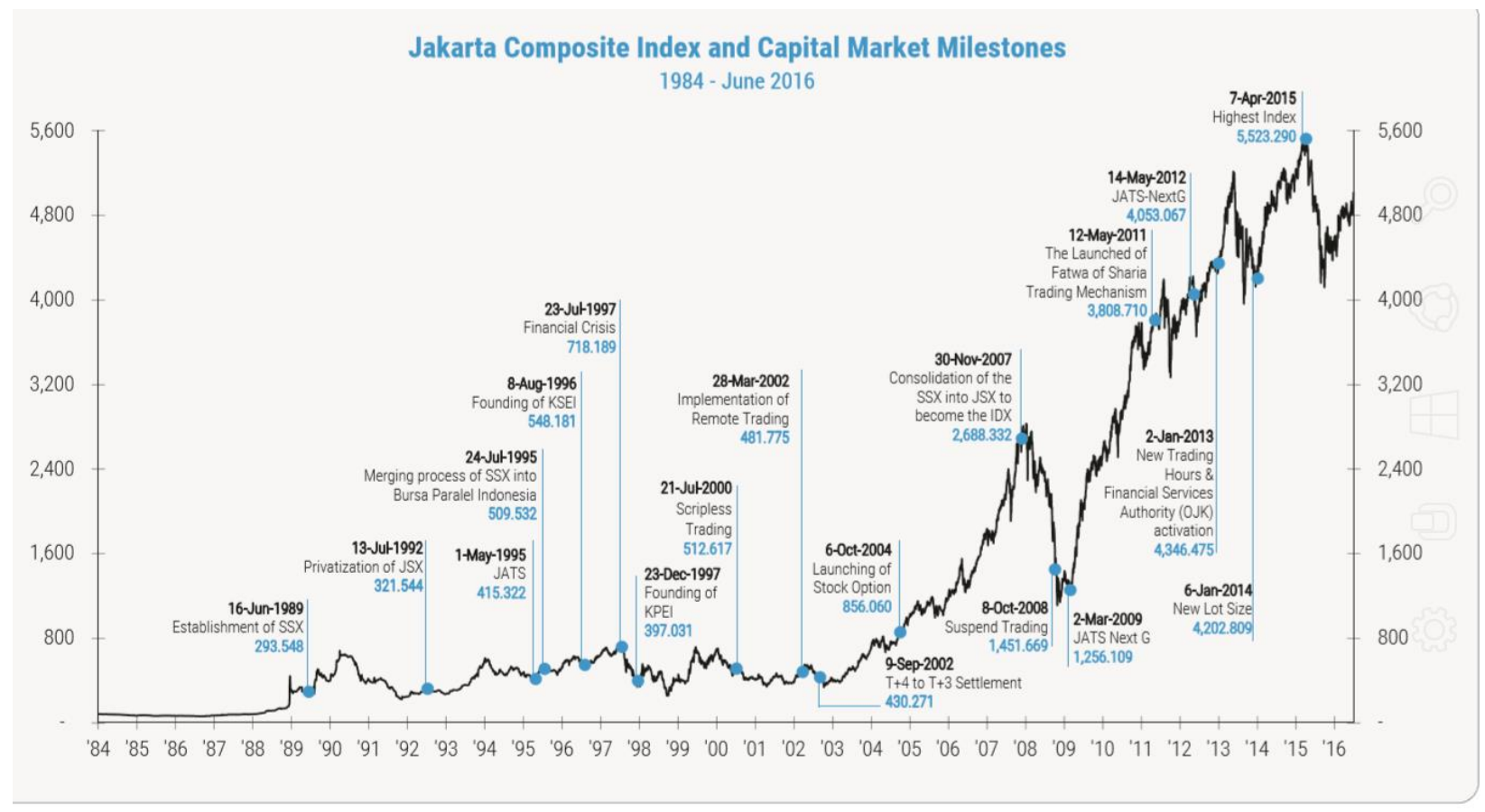

Gambar 1. Indeks Harga Saham Gabungan Tahun 2013-2015

Berdasarkan Gambar 1 menunjukkan bahwa dalam Indeks Harga Saham Gabungan pada tahun 2013-2015sudah mencakup kondisi pasar sedang bullish dan bearish.

Table 1. Kinerja IHSG

\begin{tabular}{ll}
\hline Date & Jumlah \\
\hline 2 Januari 2013 & $4.346,475$ \\
6 Januari 2014 & $4.202,809$ \\
7 April 2015 & $5.532,290$ \\
\hline
\end{tabular}

Pada Tabel 1 juga dapat dilihat bahwa terdapat rebound. Peristiwa tersebut memprediksi bahwa perilaku herding hadir pada saham LQ-45 di Pasar Modal Indonesia. Pergerakan Indeks Harga Saham Gabungan selaras dengan 
pergerakan Indeks LQ-45 pada tahun 2013-2015. Maka dalam menjadikan saham yang terdapat dalam Indeks LQ-45 sebagai bagian dari populasi dan sampel, penelitian dapat menggambarkan keadaan Pasar Modal Indonesia.

Penelitian ini bertujuan untuk menganalisis keberadaan perilaku herding saat kondisi pasar turun dan pada saat kondisi pasar naik pada saham LQ-45 di Pasar Modal Indonesia. Penelitian ini diharapkan dapat meningkatkan pemahaman investor mengenai formasi harga di pasar saham dan menjadi bahan pertimbangan ketika berinvestasi saham LQ-45

\section{Tinjauan pustaka}

\section{Behavioral Finance}

Perilaku keuangan adalah aplikasi psikologi untuk pengambilan keputusan keuangan dan pasar keuangan. Perilaku keuangan juga merupakan transformasi paradigma keuangan dengan kerangka berdasarkan psikologis (Shefrin, 2010). Menurut Statman (1999) yang dikutip oleh Chandra (2012), behavior finance adalah penggabungan antara ilmu psikologi dan keuangan, karena sebetulnya psikologi tidak pernah terpisahkan dari ilmu keuangan. Dapat disimpulkan bahwa behavioral finance adalah ilmu yang mempelajari bagaimana manusia mengambil tindakan pada proses pengambilan keputusan investasi sebagai respon dan informasi yang telah diperoleh.

\section{Hipotesis Pasar Efisien}

Hipotesis pasar efisien adalah hipotesis dimana harga saham telah mencerminkan seluruh informasi yang tersedia. Menurut Fama (1970) dalam Nuffus (2013), hipotesis pasar efisien terdiri dari 3 bentuk, yaitu: (1) Hipotesis bentuk lemah (weak form) yaitu menyebutkan bahwa harga saham telah mencerminkan seluruh informasi yang dapat diturunkan dengan menguji data perdagangan pasar berupa harga historis, volume perdagangan, dan bunga pinjaman. (2) Hipotesis bentuk semi kuat (semi strong form) yaitu menyebutkan bahwa harga saham pada pasar modal menggambarkan semua informasi yang dipublikasikan seperti earning, deviden, pengumuman stock split, penerbitan saham dan kesulitan keuangan yang dialami perusahaan. (3) Hipotesis bentuk kuat (strong form) yaitu menyatakan bahwa harga pasar mencerminkan seluruh informasi yang relevan bagi perusahaan, termasuk informasi yang hanya tersedia bagi orang dalam perusahaan.

Perilaku Herding

Menurut Bikchandani dan Sharma (2001) dalam Chasanah (2015), herding merupakan fenomena terjadinya pembelian atau penjualan secara berkelompok atas satu atau lebih saham secara berkelompok yang terjadi di pasar modal atau bursa. Menurut Lan dan Rose (2011), perilaku herding digambarkan sebagai kecenderungan orang untuk mengikuti orang lain untuk membuat keputusan investasi yang identik, dimana sedikit informasi publik yang tersedia. Investor tertarik dimana mereka dapat membuat profit dengan mengandalkan informasi kolektif dari pada informasi pribadi.

Penyebab Perilaku Herding

Menurut Chang, Cheng dan Kharona (2000) dalam Tristantyo (2014), memberikam 4 alasan mengapa investor instuisi bertransaksi pada arah yang sama:

1. Investor mengolah informasi yang sama.

2. Investor lebih memilih saham dengan ciri-ciri yang umum yaitu "better-known" dan "liquid".

3. Para manajer cenderung mengikuti langkah transaksi yang diikuti oleh manajer lain untuk menjaga reputasinya.

4. Para manajer mangikuti valuasi harga saham dari manajer lainnya.

\section{Dampak Perilaku Herding}

Lao dan Shingh (2011) memaparkan bahwa ketika informasi seorang investor berdasarkan pada informasi kolektif dari pada informasi pribadi, nilai fundamental dari saham bisa rendah. Selain itu, Menurut Hwang dan Salmon (2004) dalam Golarzi dan Ziyachi (2013), menyebutkan dampak perilaku herding yaitu munculnya fenomena-fenomena 
seperti peningkatan fluktuasi harga saham, jatuhnya harga, efek kalender, perbedaan return saham, tidak equilibriumnya antara harga dan variabel fundamnetal menuju pada pasar tidak efisien.

Return Saham

Menurut Jogiyanto (2013), Return adalah keuntungan yang diperoleh atau dihasilkan dari kegiatan investasi. Return dapat berupa return realisasi yang sudah terjadi atau return ekspektasi yang belum terjadi tetapi masih diharapkan akan terjadi dimasa mendatang. Return realisasi dihitung berdasarkan data historis. Sedangkan menurut Tandelin (2010), return adalah salah satu faktor yang memotivasi investor berinvestasi dan juga merupakan imbalan atas keberanian investor menanggung resiko atas investasi yang dilakukannya.

Table 2. Review Penelitian Terdahulu.

\begin{tabular}{|c|c|c|c|c|c|}
\hline No & Column A $(t)$ & & & & Column B $(t)$ \\
\hline 1 & $\begin{array}{l}\text { Gamage dan } \\
\text { Thushari(2016) }\end{array}$ & $\begin{array}{l}\text { Herding in Colombo } \\
\text { Stock Exchange }\end{array}$ & $\begin{array}{l}\text { CSAD dan } \\
\text { Return pasar }\end{array}$ & Analisis Regresi & $\begin{array}{l}\text { Perilaku herding tidak hadir pada Bursa Efek } \\
\text { Kolombo }\end{array}$ \\
\hline 2 & $\begin{array}{l}\text { Nuffus dan } \\
\text { Chandra (2013) }\end{array}$ & $\begin{array}{l}\text { Analisis Perilaku } \\
\text { Herding pada Saham } \\
\text { Kompas } 100 \text { yang } \\
\text { terdaftar di Bursa Efek } \\
\text { Indonesia 2008-2012 }\end{array}$ & $\begin{array}{l}\text { CSAD dan } \\
\text { Return pasar }\end{array}$ & Analisis Regresi & $\begin{array}{l}\text { Selama periode penelitian tidak ditemukan } \\
\text { perilaku herding di Bursa Efek Indonesia }\end{array}$ \\
\hline 3 & $\begin{array}{l}\text { Ahsan dan } \\
\text { Sarkar (2013) }\end{array}$ & $\begin{array}{l}\text { Herding in Dhaka } \\
\text { Stock Exchange }\end{array}$ & $\begin{array}{l}\text { CSAD dan } \\
\text { Return pasar }\end{array}$ & Analisis Regresi & $\begin{array}{l}\text { Selama periode penelitian tidak ditemukan } \\
\text { perilaku herding di Bursa Efek Indonesia }\end{array}$ \\
\hline 4 & $\begin{array}{l}\text { Gunawan et al } \\
\text { (2011) }\end{array}$ & $\begin{array}{l}\text { Pendeteksian Perilaku } \\
\text { Herding pada Pasar } \\
\text { Saham Indonesia dan } \\
\text { Asia Pasifik }\end{array}$ & $\begin{array}{l}\text { CSAD dan } \\
\text { Return Pasar }\end{array}$ & $\begin{array}{l}\text { Analisis regresi } \\
\text { Kuartil }\end{array}$ & $\begin{array}{l}\text { Perilaku Herding terjadi pada saat kondisi } \\
\text { market stress di Pasar Saham Indonesia dan } \\
\text { pasar Saham Asia Pasifik }\end{array}$ \\
\hline 5 & $\begin{array}{l}\text { Lao dan Singh } \\
\text { (2011) }\end{array}$ & $\begin{array}{l}\text { Herding Behaviour in } \\
\text { the Chinese and Indian } \\
\text { Stock Markets }\end{array}$ & $\begin{array}{l}\text { CSAD, dan } \\
\text { Return Pasar }\end{array}$ & Analisis Regresi & $\begin{array}{l}\text { Perilaku herding terjadi di pasar modal India } \\
\text { ketika kondisi tren pasar naik. }\end{array}$ \\
\hline 6 & $\begin{array}{l}\text { Lan dan Rose } \\
\text { (2011) }\end{array}$ & $\begin{array}{l}\text { Herding and Trading } \\
\text { Volume }\end{array}$ & $\begin{array}{l}\text { CSAD dan } \\
\text { return pasar }\end{array}$ & $\begin{array}{l}\text { Analisis Regresi } \\
\text { dan VAR }\end{array}$ & $\begin{array}{l}\text { 1.Perilaku Herding hadir di Pasar Modal } \\
\text { hongkong ketika tren pasar sedang menurun. } \\
\text { 2.Perilaku Herding merupakan fenomena } \\
\text { jangka panjang di Hong Kong. }\end{array}$ \\
\hline
\end{tabular}

\section{Kerangka Konseptual}

Untuk menganalisis perilaku herding dalam penelitian ini, peneliti menggunakan metode yang dipelopori oleh Chang, Cheng dan Kharona (2000). Ketika investor membuat keputusan investasi dengan mengikuti konsensus pasar, maka return saham tidak akan terdeviasi terlalu jauh dari return pasar. Akibatnya dispersi return saham akan relatif rendah dan hubungan non-linier antara dispersi return saham dan rata-rata return pasar akan terbentuk. Tingkat dispersi return saham diukur dengan Cross-Sectional Absolute Deviation (CSAD) terhadap return pasar. Kerangka konseptual penelitian ini tentang hubungan antara return pasar dan Cross-Sectional Absolute Deviation (CSAD)pada saham LQ-45.

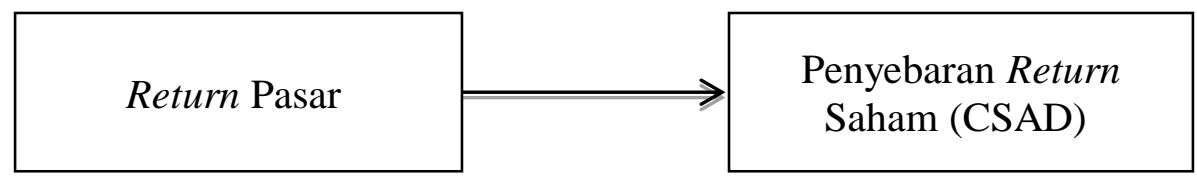

Gambar 2.2 kerangka konseptual

Berdasarkan kerangka konseptual, maka hipotesis dalam penelitian ini adalah: 
1. Terdapat perilaku herding saat kondisi pasar turun pada saham LQ-45 di Pasar Modal Indonesia yang ditandai dengan adanya hubungan yang signifikan antara imbal balik pasar dan Cross-Sectional Absolute Deviation.

2. Terdapat perilaku herding saat kondisi pasar naik pada saham LQ-45 di Pasar Modal Indonesia yang ditandai dengan adanya hubungan yang signifikan antara imbal balik pasar dan Cross-Sectional Absolute Deviation

\section{Metode Penelitian}

Jenis Data, Tempat dan Waktu Penelitian

Jenis data yang digunakan dalam penelitian ini adalah data sekunder perusahaan yang listed dalam indeks LQ-45. Data yang digunakan adalah daftar harga saham harian pada perusahaan LQ-45 dan Indeks LQ-45 untuk tahun 2013 sampai dengan 2015. Penelitian ini dilakukan di Bursa Efek Indonesia dengan mengakses situs Bursa Efek Indonesia: www.idx.co.id, www.sahamok.com dan www.finance.yahoo.com atau www.duniainvestasi.com.

\section{Populasi dan Sampel}

Populasi dalam penelitian ini adalah semua perusahaan yang terdaftar dalam indeks LQ-45 di Bursa Efek Indonesia dari 2013 sampai dengan 2015. Penentuan sampel dalam penelitian ini dengan menggunakan metode purposive sampling, yaitu sampel yang digunakan untuk memperkirakan karakteristik populasi berdasarkan pada kriteria tertentu. Berikut ini adalah kriteria yang digunakan peneliti dalam penentuan sampel: (1) Perusahaan yang terdaftar di Bursa Efek Indonesia dan sahamnya masuk dalam indeks LQ-45 pada periode 2013 sampai 2015, (2) Perusahaan yang sahamnya selalu konsisten listed dalam indeks LQ-45 pada periode 2013 sampai 2015. (3) Perusahaan yang memiliki data historis harga saham yang lengkap dalam indeks LQ-45 pada periode 2013 sampai 2015. Jumlah populasi dalam penelitian ini adalah 63 perusahaan yang pernah masuk dan list saham LQ-45 selama periode pengamatan. Perusahaan memenuhi kriteria penarikan sampel adalah 29 perusahaan.

\section{Definisi Operasional Variabel}

Penelitian ini adalah penelitian asosiatif, yaitu penelitian yang bertujuan untuk mengetahui hubungan antara return pasar dan Cross-Sectional Absolute Deviation (CSAD). Metode pengumpulan data yang digunakan dalam penelitian ini adalah studi dokumentasi, yaitu mengumpulkan data yang berhubungan dengan perusahaan LQ-45 dan Indeks LQ45. Berikut ini merupakan tabel defenisi operasional, yaitu:

Tabel 3. Operasional Variabel

\begin{tabular}{rlcc}
\hline Variabel & \multicolumn{1}{c}{ Defenisi Variabel } & Indikator & Skala Ukur \\
\hline Return Pasar & $\begin{array}{l}\text { Imbal balik dari keseluruhan } \\
\text { portofolio pasar. }\end{array}$ & $R_{m, t}=\frac{P_{m, t}-P_{m, t-1}}{P_{m, t-1}}$ & Rasio
\end{tabular}

Cross-Sectional Dispersi atau tingkat penyebaran

Absolute Deviation imbal balik saham.

(CSAD)

$$
\operatorname{CSAD}_{t}=\frac{1}{N} \sum_{i=1}^{N}\left|R_{i, t}-R_{m, t}\right| \quad \text { Rasio }
$$

\section{Metode analisis data}

Data sampel yang telah terkumpulkan diolah menjadi input variabel untuk mencari tingkat dispersi saham dengan menggunakan model Cross-Sectional Absolute Deviation (CSAD). Untuk mendeteksi perilaku herding dilakukan langkah-langkah sebagai berikut:

1. Menghitung nilai $R_{m, t}$ dan $R_{m, t}^{2}$

Nilai $R_{m, t}$ dan $R_{m, t}{ }^{2}$ dihitung berdasarkan pada nilai dari return pasar. Untuk data pasar digunakan Indeks LQ-45 dengan rumus sebagai berikut: 


$$
R_{m, t}=\frac{P_{m, t}-P_{m, t-1}}{P_{m, t-1}}
$$

2. $\quad$ Menghitung nilai $R_{i, t}$

Nilai $R_{i, t}$ dihitung berdasarkan pada nilai dari return saham dengan menggunakan data saham LQ-45 dengan rumus sebagai berikut:

$$
R_{i, t}=\frac{P_{i, t}-P_{i, t-1}}{P_{i, t-1}}
$$

3. Menghitung nilai CASD

Nilai CSAD dihitung menggunakan metode Chang, Cheng dan Kharona (2000) dengan rumus sebagai berikut:

$$
C S A D_{t}=\frac{1}{N} \sum_{i=1}^{N}\left|R_{i, t}-R_{m, t}\right|
$$

Teknik analisis data yang digunakan adalah analisis regresi sederhana. Analisis regresi dilakukan untuk melihat hubungan variabel bebas (X) dan variabel (Y). Untuk melihat kehadiran perilaku Herding, maka dilakukan analisis regresi sederhana model kuadrat dalam persamaan berikut:

$$
\begin{aligned}
& C S A D_{t}{ }^{D O W N}=\propto+\gamma_{1}{ }^{D O W N}\left|R_{m, t^{D O W N}}\right|+\gamma_{2}{ }^{D O W N}\left(R_{m, t^{D O W N}}\right)^{2}+\varepsilon_{t} \\
& C S A D_{t}{ }^{U P}=\propto+\gamma_{1}{ }^{U P}\left|R_{m, t}{ }^{U P}\right|+\gamma_{2}{ }^{U P}\left(R_{m, t^{U P}}\right)^{2}+\varepsilon_{t}
\end{aligned}
$$

Kondisi pasar naik didefenisikan ketika return pasar positif, Kondisi pasar turun didefenisikan ketika return pasar negatif. Jika $\gamma_{2}^{U P}$ bernilai negatif, hal ini mengindikasikan kehadiran perilaku herding saat kondisi pasar naik. Jika $\gamma_{2}^{D O W N}$ bernilai negatif, maka diindikasikan adanya perilaku herding saat kondisi pasar turun.

\section{Hasil Penelitian}

Analisis Statistik Deskriptif

Analisis statistik deskriptif kondisi pasar turun

Tabel 4. Statistik Deskriptif Kondisi Pasar Turun Periode 2013-2015

\begin{tabular}{llll}
\hline & CSAD & ABS_RMT & RMT2 \\
\hline Mean & 0.001003 & 0.001730 & $5.63 \mathrm{E}-06$ \\
Maximum & 0.004094 & 0.005854 & $3.43 \mathrm{E}-05$ \\
Minimum & $4.81 \mathrm{E}-05$ & $6.70 \mathrm{E}-05$ & $4.00 \mathrm{E}-09$ \\
Std. Dev. & 0.001027 & 0.001674 & $9.25 \mathrm{E}-06$ \\
Observations & 17 & 17 & 17 \\
\hline
\end{tabular}

Sumber: Hasil Penelitian, 2017 (Data Diolah)

Berdasarkan Tabel 4 menunjukkan bahwa selama pada periode Januari 2013 sampai Desember 2015 ada 17 bulan pengamatan dengan return pasar bernilai negatif yang digunakan untuk menggambarkan kondisi pasar turun dalam penelitian ini. Variabel Cross Sectional Absolute Deviation (CSAD) saat pasar turun memiliki nilai minimum 0,0000481 yaitu bulan Juni 2014, nilai maksimum 0,004094 yaitu bulan Agustus 2013 dan nilai rata-rata sebesar 0,001003 dengan standar deviasi 0,001027. Variabel return pasar (Abs Rmt) saat pasar turun memiliki nilai minimum 0,000067yaitu bulan Oktober 2014, nilai maksimum 0,005854 yaitu pada bulan Agustus 2013 dan nilai rata-rata sebesar 0,001730 dengan standar deviasi 0,001674. Variabel return pasar $\left(\mathrm{Rmt}^{2}\right)$ saat pasar turun memiliki nilai 
minimum 0,000000004 yaitu pada bulan Oktober 2014, nilai maksimum 0,0000343 yaitu pada Agustus 2013 dan nilai rata-rata sebesar 0,00000563 dengan standar deviasi 0,00000925 .

Analisis statistik deskriptif kondisi pasar naik

Statistik deskriptif kondisi pasar naik (bullish) digunakan untuk memberi gambaran umum data objek penelitian ketika return pasar bernilai positif. Hasil statistik deskriptif untuk seluruh variabel penelitian ketika pasar naik dapat dilihat pada Tabel 5 berikut:

Tabel 5. Statistik Deskriptif Kondisi Pasar Naik Periode 2013-2015

\begin{tabular}{cccc}
\hline & CSAD & ABS_RMT & RMT2 \\
\hline Mean & 0.000498 & 0.001722 & $4.15 \mathrm{E}-06$ \\
Maximum & 0.001439 & 0.003906 & $1.53 \mathrm{E}-05$ \\
Minimum & $2.50 \mathrm{E}-05$ & 0.000440 & $1.94 \mathrm{E}-07$ \\
Std. Dev. & 0.000332 & 0.001119 & $4.57 \mathrm{E}-06$ \\
Observations & 19 & 19 & 19 \\
\hline
\end{tabular}

Sumber: Hasil Penelitian, 2017 (Data Diolah)

Berdasarkan Tabel 5 menunjukkan bahwa selama pada periode Januari 2013 sampai Desember 2015 ada 19 bulan pengamatan dengan return pasar bernilai positif yang digunakan untuk menggambarkan kondisi pasar naik dalam penelitian ini. Variabel Cross Sectional Absolute Deviation (CSAD) saat pasar naik memiliki nilai minimum 0,000025 yaitu bulan Oktober 2013, nilai maksimum 0,001439 yaitu bulan Maret 2015 dan nilai rata-rata sebesar 0,000498 dengan standar deviasi 0.000332. Variabel return Pasar (Abs Rmt) saat pasar naik memiliki nilai minimum 0,000440 yaitu bulan Maret 2015, nilai maksimum 0,003906 yaitu bulan Februari 2013 dan nilai rata-rata sebesar 0,001722 dengan standar deviasi $\quad 0,001119$. Variabel return pasar $\left(\mathrm{Rmt}^{2}\right)$ saat pasar naik memiliki nilai minimum $\quad 0,000000194$ yaitu bulan Maret 2015, nilai maksimum 0,0000153yaitu bulan Februari 2013, dan nilai rata-rata sebesar 0,00000415 dengan standar deviasi 0,00000457 .

Analisis regresi

Analisis regresi kondisi pasar turun

Model analisis yang digunakan dalam penelitian ini dalam kondisi pasar turun adalah regresi sederhana dengan persamaan sebagai berikut:

$$
C S A D_{t}{ }^{\text {DOWN }}=\propto+\gamma_{1}{ }^{\text {DOWN }}\left|R_{m, t^{\text {DOWN }}}\right|+\gamma_{2}{ }^{\text {DOWN }}\left(R_{m, t^{\text {DOWN }}}\right)^{2}+\varepsilon_{t}
$$

Dari hasil pengolahan data dengan perangkat lunak Eviews 8 diperoleh hasil pada Tabel 6 berikut:

Tabel 6. Hasil Analisis Regresi Kondisi Pasar Turun Periode 2013-2015

\begin{tabular}{lllll}
\hline $\begin{array}{l}\text { Dependent Variable: CSAD } \\
\text { Method: Least Squares }\end{array}$ & & & \\
$\begin{array}{l}\text { Date: 07/11/17 Time: 15:34 } \\
\text { Sample: 2013M05 2015M11 } \\
\text { Included observations: } 17\end{array}$ & & & & \\
Variable & Coefficient & Std. Error & t-Statistic & Prob. \\
\hline & & & & \\
ABS_RMT & -0.133352 & 0.436995 & -0.305155 & 0.7647 \\
RMT2 & 91.81339 & 79.08752 & 1.160909 & 0.2651 \\
C & 0.000716 & 0.000412 & 1.739003 & 0.1040
\end{tabular}




\begin{tabular}{lllr} 
R-squared & 0.387544 & Mean dependent var & 0.001003 \\
Adjusted R-squared & 0.300051 & S.D. dependent var & 0.001027 \\
S.E. of regression & 0.000859 & Akaike info criterion & -11.12299 \\
Sum squared resid & $1.03 E-05$ & Schwarz criterion & -10.97595 \\
Log likelihood & 97.54538 & Hannan-Quinn criter. & -11.10837 \\
F-statistic & 4.429401 & Durbin-Watson stat & 1.177341 \\
Prob(F-statistic) & 0.032324 & & \\
\hline
\end{tabular}

Sumber: Hasil Penelitian, 2017 (Data Diolah)

Berdasarkan Tabel 6 persamaan regresi saat kondisi pasar turun dalam penelitian ini adalah :

$$
\operatorname{CSAD}_{t}^{\text {DOWN }}=0,000716-0,133352\left|R_{m, t^{\text {DOWN }}}\right|+91,81339\left(R_{m, t^{\text {DOWN }}}\right)^{2}+\varepsilon_{t}
$$

$C S A D_{t}^{D O W N}=$ Cross Sectional Absolute Deviation periode saat kondisi pasar turun

$\mathrm{R}_{\mathrm{m}, \mathrm{t}}{ }^{\text {DOWN }}=$ Return portofolio pasar periode $\mathrm{t}$ saat kondisi pasar turun

Hasil regresi sederhana dapat diinterpretasikan sebagai berikut:

Nilai kosntanta sebesar 0,000716 artinya apabila nilai return pasar $\left(\left|\mathrm{R}_{\mathrm{m}, \mathrm{t}}{ }^{\text {DOwN }}\right|\right.$ dan $\left.\mathrm{Rmt}^{2}\right)$ bernilai konstan atau nol, maka Cross Sectional Absolute Deviation (CSAD) bernilai 0,000716\%.Nilai koefisien linier antara CSAD dan return pasar $\mid \mathrm{R}_{\mathrm{m}, \mathrm{t}}$ DOwN $\mid$ sebesar $-0,133352 \%$. Nilai ini tidak signifikan dan negatif, serta menunjukkan CSAD menurun terhadap $\mid R_{m, t}$ DOwN $\mid$. Jika return pasar sebesar $1 \%$ maka CSAD akan menurun $0,133352 \%$. Nilai koefisien non-linier antara CSAD dan return pasar $\left(\mathrm{Rmt}^{2}\right)$ sebesar 91,81339. Nilai ini tidak signifikan dan positif artinya tidak menunjukkan indikasi adanya perilaku herding pada saham LQ-45 saat kondisi pasar turun (bearish).

\section{Analisis Regresi Kondisi Pasar Naik}

Model analisis yang digunakan dalam penelitian ini saat kondisi pasar naik adalah regresi sederhana dengan persamaan sebagai berikut:

$$
\operatorname{CSAD}_{t}{ }^{U P}=\propto+\gamma_{1}{ }^{U P}\left|R_{m, t}{ }^{U P}\right|+\gamma_{2}{ }^{U P}\left(R_{m, t} U P\right)^{2}+\varepsilon_{t}
$$

Dari hasil pengolahan data dengan perangkat lunak eviews 8 diperoleh hasil pada table 7 berikut :

Tabel 7. Hasil Analisis Regresi Kondisi Pasar Naik Periode 2013-2015

$\begin{array}{lllll}\begin{array}{l}\text { Dependent Variable: CSAD } \\ \text { Method: Least Squares }\end{array} & & & \\ \text { Date: 07/11/17 Time: 15:43 } & & & \\ \begin{array}{l}\text { Sample: 2013M01 2015M12 } \\ \text { Included observations: } 19\end{array} & & & \\ & \text { Coefficient } & \text { Std. Error } & \text { t-Statistic } & \text { Prob. } \\ \text { Variable } & -0.561922 & 0.277484 & -2.025060 & 0.0599 \\ \text { ABS_RMT } & 108.3319 & 67.99241 & 1.593294 & 0.1307 \\ \text { RMT2 } & & & & \end{array}$




\begin{tabular}{|c|c|c|c|}
\hline $\mathrm{C}$ & 0.001016 & 0.000223 & 0.0003 \\
\hline $\mathrm{R}$-squared & 0.305180 & Mean dependent var & 0.000498 \\
\hline Adjusted R-squared & 0.218327 & S.D. dependent var & 0.000332 \\
\hline S.E. of regression & 0.000293 & Akaike info criterion & -13.28662 \\
\hline Sum squared resid & $1.38 \mathrm{E}-06$ & Schwarz criterion & -13.13749 \\
\hline Log likelihood & 129.2229 & Hannan-Quinn criter. & -13.26138 \\
\hline F-statistic & 3.513767 & Durbin-Watson stat & 2.502455 \\
\hline Prob(F-statistic) & 0.054323 & & \\
\hline
\end{tabular}

Sumber: Hasil Penelitian, 2017 (Data Diolah)

Berdasarkan Tabel 7 persamaan regresi saat kondisi pasar naik dalam penelitian ini adalah:

$$
\operatorname{CSAD}_{t}^{U P}=0,001016-0,561922\left|R_{m, t}{ }^{U P}\right|+108,3319\left(R_{m, t} U P\right)^{2}+\varepsilon_{t}
$$

$C S A D_{t}{ }^{U P}=$ Cross Sectional Absolute Deviation periode saat kondisi pasar naik

$\mathrm{R}_{\mathrm{m}, \mathrm{t}}^{\mathrm{UP}} \quad=$ Return portofolio pasar periode $\mathrm{t}$ saat kondisi pasar naik

Hasil regresi sederhana dapat diinterpretasikan sebagai berikut:

Nilai kosntanta sebesar 0,001016 artinya apabila nilai return pasar $\left(\left|\mathrm{R}_{\mathrm{m}, \mathrm{t}}^{\mathrm{UP}}\right|\right.$ dan $\left.\mathrm{Rmt}^{2}\right)$ bernilai konstan atau non, maka Cross Sectional Absolute Deviation (CSAD) bernilai 0,001016\%.Nilai koefisien linier antara CSAD dan return pasar $\mid R_{m, t}$ UP $\mid$ sebesar $-0,561922 \%$. Nilai ini tidak signifikan dan negatif, serta menunjukkan CSAD menurun terhadap $\left|\mathrm{R}_{\mathrm{m}, \mathrm{t}} \mathrm{UP}\right|$. Jika return pasar meningkat sebesar $1 \%$ maka CSAD akan menurun 0,561922\%.Nilai koefisien non-linier antara CSAD dan return pasar $\left(\mathrm{Rmt}^{2}\right)$ sebesar 108,3319. Nilai ini tidak signifikan dan positif artinya tidak menunjukkan indikasi adanya perilaku herding pada saham LQ-45 saat kondisi pasar turun (bearish).

\section{Pembahasan}

\section{Perilaku herding saat kondisi pasar turun}

Berdasarkan hasil penelitian yang telah dijelaskan sebelumnya, menunjukkan bahwa perilaku herding tidak hadir pada Saham LQ-45 di Pasar Modal Indonesia dalam kondisi pasar turun. Hal ini dapat diketahui dari nilai koefisien non-linier $\left(\gamma_{2}{ }^{\text {DOWN }}\right)$ antara CSAD dan return pasar $\left(\mathrm{Rmt}^{2}\right)$ pada saat kondisi pasar turun tidak signifikan sebesar 91,81339. Maka dapat disimpulkan bahwa ketika return pasar tidak signifikan, investor akan cenderung tidak mengikuti konsensus pasar. Hal ini mengindikasikan bahwa tidak ada indikasi perilaku herding pada Saham LQ-45 saat kondisi pasar turun (bearish) selama periode penelitian.

Hal ini menjelaskan bahwa investor pada Saham LQ-45 selama periode penelitian memiliki perilaku yang rasional dalam mengambil keputusan investasinya, dikarenakan informasi yang dibutuhkan oleh investor yang berkaitan dengan pergerakan harga saham di pasar dapat di akses dengan baik sehingga investor menjadikannya sebagai dasar analisis investasi. Bikchandani dan Sharma dalam (Dharmawan, 2015), mengungkapkan bahwa ketika memiliki keterbatasan informasi, investor cenderung mengikuti gerakan investor lain dalam mengambil keputusan investasi yang pada akhirnya akan mengabaikan signal miliknya dan mengikuti keputusan mayoritas (perilaku herding). Tidak terdeteksinya perilaku herding pada saham LQ-45 disebabkan kerena tidak terjadi market stress yang berkepanjangan selama periode 2013-2015. Pada saat market stress, investor cenderung untuk menekan pemikiran mereka dan lebih mengikuti konsensus pasar, sehingga perilaku herding cenderung terjadi.

Hasil penelitian ini mendukung penelitian (Ahsan \& Sarkar, 2013), penelitian tersebut menyatakan bahwa tidak terdapat perilaku herding pada emerging market, yaitu pada pasar saham Bangladesh. Tidak adanya perilaku herding 
pada emerging market menggambarkan bahwa investor telah berperilaku rasional dalam membuat keputusan investasi berdasarkan informasi yang tersedia di pasar daripada mengikuti konsensus pasar. Penelitian ini juga di dukung oleh penelitian (Gamage \& Thusari, 2016), yang menyatakan bahwa perilaku herding tidak hadir pada saat pasar turun di Bursa Efek Kolombo. Pada saat kondisi pasar turun, penelitian ini tidak sejalan dengan penelitian (Lan \& Rose, 2011), yang menyatakan bahwa perilaku herding hadir secara signifikan pada saat pasar turun di Hong Kong.

\section{Perilaku herding saat kondisi pasar naik}

Selama periode penelitian, menunjukkan bahwa perilaku herding tidak hadir pada Saham LQ-45 di Pasar Modal Indonesia dalam kondisi pasar naik yaitu pada 15 bulan. Pada saat kondisi pasar naik, nilai koefisien non-linier antara CSAD dan return pasar $\left(\mathrm{Rmt}^{2}\right)$ sebesar 108,3319. Ketika koefisien $\left(\gamma_{2}{ }^{U P}\right)$ ini tidak siginfikan, maka hal ini mengindikasikan tidak adanya perilaku herding pada saat kondisi pasar naik (bullish).

Hal ini juga menjelaskan bahwa investor pada Saham LQ-45 selama periode penelitian memiliki perilaku yang rasional dalam mengambil keputusan investasinya, dikarenakan informasi yang dibutuhkan oleh investor yang berkaitan dengan pergerakan harga saham di pasar dapat di akses dengan baik sehingga investor menjadikannya sebagai dasar analisis investasi. Pada saat kondisi pasar naik, penelitian ini sejalan dengan penelitian (Gunawan, Hari, Noer, \& Rahman, 2011), yang menyatakan bahwa perilaku herding tidak terjadi pada saat kondisi pasar naik di Pasar Saham Indonesia dan Pasar Saham Asia Pasifik. Penelitian ini juga di dukung oleh penelitian(Gamage \& Thusari, 2016), yang menyatakan bahwa perilaku herding tidak hadir pada saat pasar naik di Bursa Efek Kolombo.

Pada saat kondisi pasar naik, penelitian ini tidak sejalan dengan penelitian(Lao \& Shingh, 2011) yang membuktikan bahwa perilaku herding terjadi di Pasar Modal India saat kondisi pasar naik, yaitu investor yang berharap mendapatkan return positif dengan mengikuti konsensus pasar.

\section{Kesimpulan dan saran}

Kesimpulan

Berdasarkan hasil penelitian, maka kesimpulan penelitian ini adalah: (1) Saat kondisi pasar turun (bearish) yaitu return pasar bernilai negatif, perilaku herding tidak hadir di Pasar Modal Indonesia. Selama pasar turun, tidak ditemukan adanya hubungan non-linier antara CSAD dan return secara signifikan. Hal ini terlihat pada saat pasar turun nilai koefisien non-linier antara CSAD dan return pasar $\left(\mathrm{Rmt}^{2}\right)$ tidak signifikan. Sehingga dapat disimpulkan bahwa selama pasar turun pada periode pengamatan, investor di Pasar Modal Indonesia cenderung bertindak rasional dalam mengambil keputusan investasi. (2) Saat kondisi pasar naik (bullish) yaitu return pasar bernilai positif, perilaku herding tidak hadir di Pasar Modal Indonesia. Selama pasar naik, tidak ditemukan adanya hubungan non-linier antara CSAD dan return secara signifikan. Hal ini terlihat pada saat pasar naik nilai koefisien non-linier anatasa CSAD dan return pasar tidak signifikan. Sehingga dapat disimpulkan bahwa selama pasar naik pada periode pengamatan, investor di Pasar Modal Indonesia cenderung bertindak rasional dalam mengambil keputusan investasi.

Saran

Dari analisis yang telah dilakukan dan kesimpulan yang diperoleh, maka saran yang dapat diberikan adalah: (1) Bagi investor sebaiknya juga menggunakan dan memperdalam analisis fundamental ketika membuat keputusan investasi. Hal ini dilakukan untuk mengimbangi analisis teknikal yang sudah dilakukan. (2) Bagi peneliti selanjutnya yang ingin meneliti perilaku herding diharapkan diharapkan dapat menambah variabel lain yang tidak dibahas dalam penelitian ini. Peneliti selanjutnya juga diharapkan dapat memperluas sektor atau indeks saham dan menambah sampel serta periode pengamatan agar penelitian terkait perilaku herding di Pasar modal Indonesia semakin berkembang. (3) Data harga saham yang diteliti diambil dengan menggunakan data bulanan. Disarankan pada peneliti selanjutnya perlu dipertimbangkan untuk menggunakan data secara harian, yang diharapakan data tersebut akan menjelaskan secara lebih akurat mengenai harga saham, dimana dengan jumlah data yang sangat banyak, disarankan apabila ingin menggunakan data harian, maka dapat mempersingkat periode penelitian.

\section{References}

[1] Gunawan, Hari, Noer, \& Rahman. (2011). Pendeteksian Perilaku Herding Pada Pasar Saham Indonesia Dan Asia Pasifik. Forum Statistika Dan Komputasi, 16, No. 2, 16-32. 
[2] Chasanah. (2015). Analisis Pengaruh Perilaku Herding Investor Asing, Volatilitas Indeks Harga Saham Gabungan, Tingkat Inflasi, dan Kapitalisasi Pasar Terhadap Return Pasar. Universitas Diponegoro.

[3] Ramadhan, \& Muhammad. (2016). Deteksi Perilaku Herding Pada Pasar Saham Indonesia Dan Singapura. Diponegoro Journal Of Management, 5, No. 2, 1-9.

[4] IDX Fack Book 2016. hhtp://idx.com. Diakses pada 24 Januari 2017.

[5] Shefrin. (2010). Behavioralizing Finance. Foundations And Trends In Finance, 4, No. 1-2, 1-184.

[6] Chandra, M. (2012). Pengukuran Dan Analisis Investasi Perilaku Herding Pada Saham IPO Bursa Efek Indonesia Tahun 2007-2011. Tesis, Universitas Sumatera Utara. Jakarta.

[7] Nuffus M., \& Wijaya, C. (2013). Analisis Perilaku Herding Pada Saham Kompas 100 Yang Terdaftar Di Bursa Efek Indonesia $2008-2012$. FISIP Universitas Indonesia, 1-20.

[8] Chasanah. (2015). Analisis Pengaruh Perilaku Herding Investor Asing, Volatilitas Indeks Harga Saham Gabungan, Tingkat Inflasi, dan Kapitalisasi Pasar Terhadap Return Pasar. Universitas Diponegoro.

[9] Lao, \& Shingh. (2011). Herding Behaviour In The Chinese And Indian Stock Market. Journal of Asian Economics, 22, No. 6, $495-506$.

[10] Tristantyo. (2014). Analisis Perilaku Herding Berdasarkan Tipe Investor Dalam Kepemilikan Saham. Skripsi, Universitas Diponegoro.

[11] Golarzi, \& Ziyachi. (2013). Study Of The Herding Behaviours Of Investor In The Tehran Stock Exchange (TSE): A Trading Volume Approsch. Interdisciplinary Journal Of Contemporary Research In Business, 5, No. 4, 196-206. 